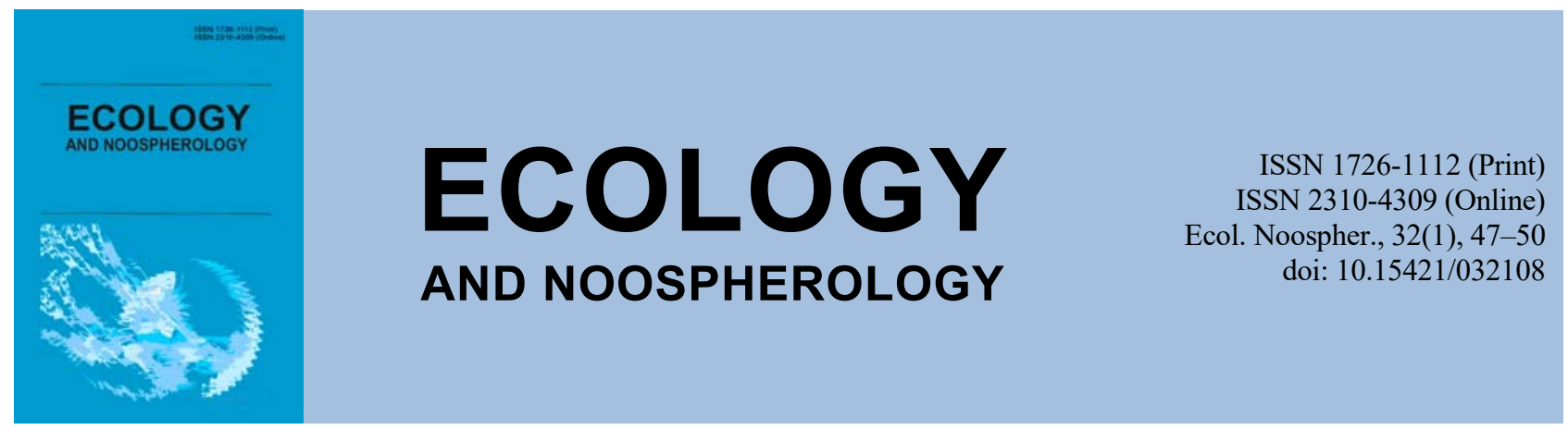

\title{
Self-restoration of woody plants in the conditions of the Botanical Garden of Dnipro National University
}

\author{
M. V. Shamray, O. Y. Pakhomov, A. M. Kabar \\ Oles Honchar Dnipro National University, Dnipro, Ukraine
}

Article info
Received 10.02.2021
Received in revised form
17.02.2021
Accepted 04.03.2021
Oles Honchar Dnipro
National University,
Gagarin Ave., 72, Dnipro,
49010, Ukraine.
Tel.: +38-066-786-52-80
E-mail: anyram@ukr.net

Article info

\begin{abstract}
Shamray, M. V., Pakhomov, O. Y., Kabar, A. M. (2021). Self-restoration of woody plants in the conditions of the Botanical Garden of Dnipro National University. Ecology and Noospherology, 32(1), 47-50. doi:10.15421/032108
\end{abstract}

\begin{abstract}
It is impossible to overestimate the importance of parks in large industrial cities. The problem of preservation of local flora together with cultivation of introduced species is more actual. The species composition of seed self-restoration of woody plants in the forest park and park parts of the Botanical Garden of Oles Honchar Dnipro National University was analyzed in order to determine the ratio of introduced and autochthonous species and whether the introduced species pose a threat to aboriginal flora. Quantitative and qualitative state of seed self-restoration determined. As a result of the research it was established that in the forest-park and park zones of the Botanical Garden artificial stands are capable of forming a sufficient number of viable undergrowth of autochthonous and introduced species, among which mainly aboriginal species dominate. The ratio of indigenous species to introduced ones in different parts of the park and forest park is $57-76 \%$ and $24-43 \%$, respectively. There is no special competition between indigenous and introduced species. Each species of woody species has adapted well to the conditions of the ecotope and to the conditions of its place of growth. Bioecological features of wood species in the plantations are not an obstacle to the development of the internal space of the ecotope, but $43 \%$ of self-regenerating woody plants in trial area 1 are introduced species, so further observation is needed.
\end{abstract}

Keywords: urban park plantations; self-restoration; dendroflora; species structure; autochthonous; introducers

\section{Introduction}

The role of parks in large cities is invaluable. The anthropogenic impact on the environment threaten the city's ecosystem, and therefore the most pressing issue is the preservation of flora, which components are the best medicine for human health and the main treasure of life, what the physician and philosopher Avicenna stated a thousand years ago.

The vegetation of parks performs many functions, not only improving the ecological situation: cleaning and humidifying the air, regulating the thermal regime of the city, which is very important in large industrial cities, but also combining health and aesthetic factors to meet people's leisure needs.

Therefore, the preservation of green areas in cities, in particular parks, is an important condition for creating a favorable urban environment in connection with significant anthropopressing.

When arranging parks, it is impossible to avoid exotic species (introduced species) for a certain area. The issue of acclimatization and introduction of plants has always interested scientists and it is found that Ukraine has significant success in the introduction and acclimatization of woody plants and the number of introduced into Ukraine species of trees and shrubs is several times higher than the number of aboriginal species that make up natural dendroflora (Kohno, 2007).
Thanks to the introduction, species of natural ecosystems are preserved, biodiversity is increased, and the living environment is improved (Kuznetsov, Sliusar, Kuznetsova, 2017). But invasive (allochthonous) species can spread spontaneously and pose a significant threat to native (autochthonous) species, displacing them from the local flora. The process of resettlement of invasive species in new territories poses the greatest threat to global biodiversity, and here we are talking about biological invasions. Invasive plant species are becoming a significant problem, displacing native plant species, which impoverishes the natural flora.

\section{Material and methods}

The researches were carried out according to the generally accepted botanical and ecological - geographical methods, the results of own field researches served as materials of work.

Trial areas 1, 2 of the Botanical Garden of DNU, Kavun at al. (2009), sector 40A, located in the forest park part of the Botanical Garden and trial area 3 of the former Yuri Gagarin park, sector 40B, currently existing in the structure of the Botanical Garden (Onishchenko, 2007) were selected as the objects of the study (Fig. 1). 


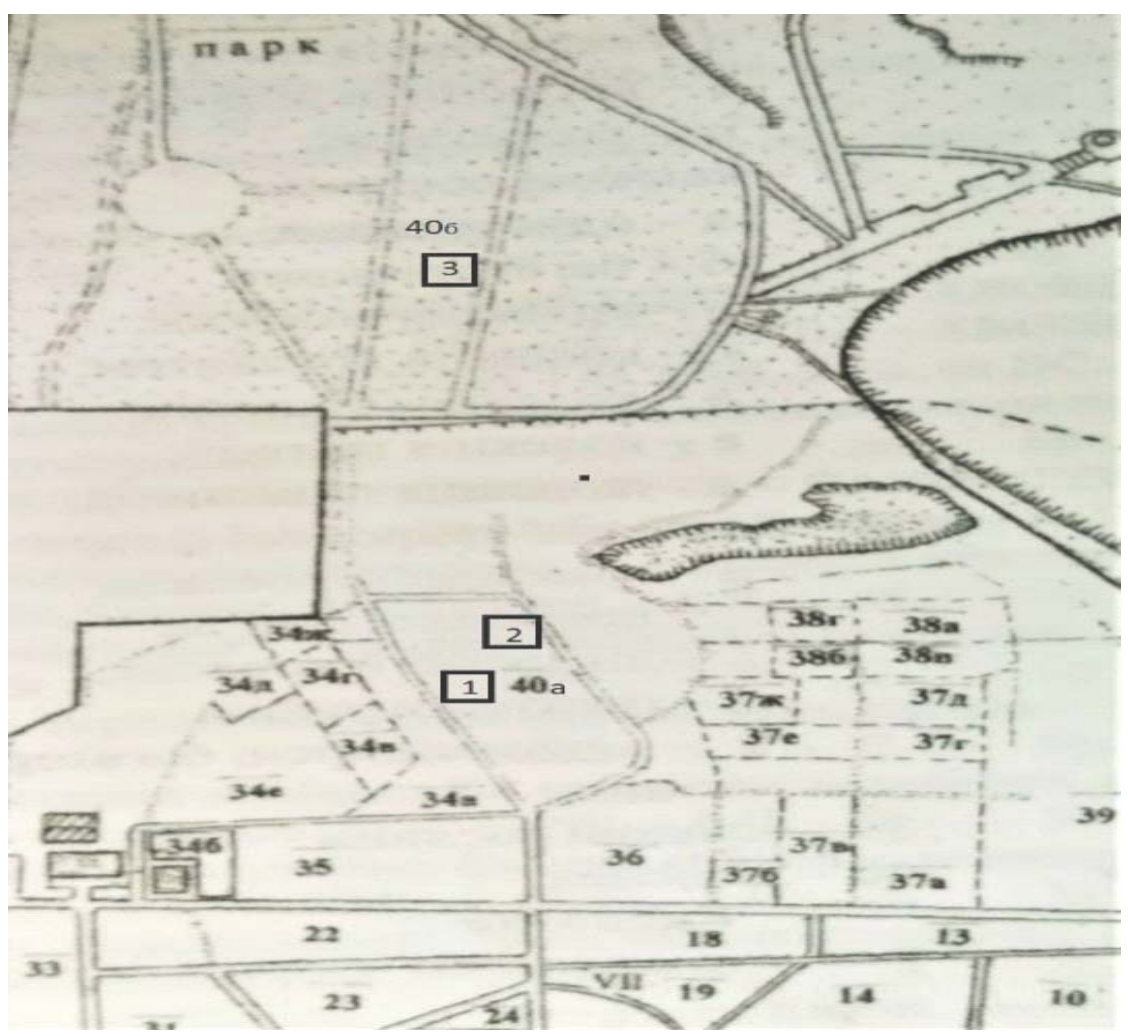

Fig. 1. Scheme of the studied areas

The research area is a part of the urbanized territory of the Dnipro-city, which is located in the south-eastern part of Ukraine within the Steppe Dnipro region (Belgard, 1950), in the subzone of forb-fescue-feather grass steppe, which are under the active influence of the urban environment. According to a soil research data, the soils, which are belonging to the subtype of ordinary forest-improved low-humus powerful weakly alkaline medium loam on loess urban chernozem soils, the class of surface-transformed natural soils, the group of natural-anthropogenic soils, similar to the soils under artificial forest plantations of the steppe zone of Ukraine, are formed in these areas. The content of humus in the surface layer of the soils reaches $5.28 \%$, the level of actual acidity -7.7 , the content of dry sediment of water extract $-0.048 \%$, the content of available to plants forms of nitrate nitrogen $-0.8 \mathrm{mg} / 100 \mathrm{~g}$, phosphorus $-12.48 \mathrm{mg} / 100 \mathrm{~g}$, potassium $-16.58 \mathrm{mg} / 100 \mathrm{~g}$. The nature of humus indicates an accumulative-humus process. In the surface layer the soil is characterized by fulvate-humate type of organic matter formation (Cha / $\mathrm{Cfa}=1,2)$, which is replaced by humate one $(\mathrm{Cha} / \mathrm{Cfa}=2,5)$ with the depth of the soil profile. The nature of the migration of organo-mineral substances in the area is slow, which corresponds to similar indicators of forest groups (litter turnover rate - 2.74) (Kabar, 2003).

An important aspect of urban green infrastructure management is the treatment of native and introduced species: whether the latter pose a threat to native species as invasive, which can create problems for the conservation of aboriginal species (Suslova, Polyakov, Kharkhota, 2013; Laptiev, 2001; Polyakov, 2009).

The aim of the work was to determine the species composition, ratio and age structure of woody species of the forest park and park zone of the Botanical Garden of DNU in Dnipro-city and to investigate the qualitative and quantitative state of seed self-restoration of introduced and autochthonous species.

\section{Results and discussion}

The following species are presented in the stand and in the shrub layer in the trial area 1: false acacia (Robinia pseudoacacia L.), ash-leaf maple (Acer negundo L.), common hackberry (Celtis occidentalis L.), Norway maple (Acer platanoides L.), green ash (Fraxinus pennsylvanica Marsh.), common ash (Fraxinus excelsior L.), field maple (Acer campestre L.), common oak (Quercus robur L.), common cherry (Prunus padus L.), single specimens: Caucasian hackberry (Celtis caucasica Willd.), asiatic elm (Ulmus pumila L.), virginia bird cherry (Prunus virginiana L.), Tatarian honeysuckle (Lonicera tatarica L.), hawthorn (Crataegus monogyna Jacq.). The height of the upper tier of the crowns of woody plant species in the stand is sometime $15-20 \mathrm{~m}$. These are artificially planted plants of common robinia, ash maple, common hackberry, which make up $12 \%$ of the total number of woody plants of the trial area 1 and are about $70-73$ years old. However, this trial area also has a significant number of young seed-restorating plants ( $88 \%$ ), including maple $-28 \%$, ash maple $-18 \%$, green ash $-14 \%$, ash $-12 \%$, common hackberry $-11 \%$, field maple $-10 \%$, common oak $-7 \%$, which grew by natural restoration (Fig. 2). Introduced, potentially invasive plant species: ash maple, green ash, common hackberry, ground elm, virgin bird cherry, Tatar honeysuckle make up $43 \%$ of the total number of the woody plants that were self-restored. Crown closure in this plantation is 0.8 , light structure semi-shadow and shadow with separate windows in the canopy. The type of moisturizing is rather fresh. The grass cover is mixed, from the sinus structure to the infusions of individual species, such as urban gravel (Geum urbanum L.), wood violet (Viola odorata L.), wild five-leafed grapes (Parthenocíssus quinquefolia (L.) Planch.).

Field maple, common hackberry, Caucasian hackberry, green ash, common maple, common ash, European white elm (Ulmus laevis Pall.) and ash maple are presented in the stand and in the bush tier in trial area 2. There are single plants of such species: false acacia, common oak, red oak (Quercus rubra L.), barberry or mahogany (Berberis aquifolium Pursh.).

The height of the stand is $15-20 \mathrm{~m}$. Crown closure in the plantation is $0.8-0.9$, the light structure is partial shade, the type of moisture is rather fresh. The upper tier of the plantation includes common hackberry, Caucasian hackberry, false acacia and European white elm. All of them make up $3.4 \%$ of the total number of woody species in the entire trial area. They are artificially planted plants with a current age of about 70- 


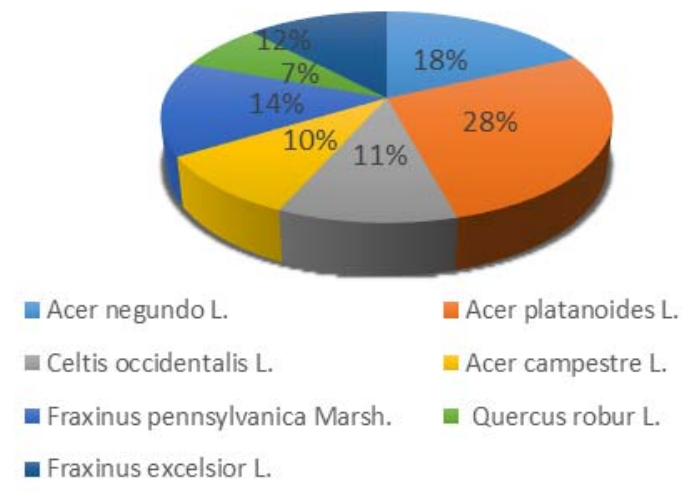

Fig. 2. The ratio of woody plant species of seed restoration in the trial area 1

73 years. In the area under the main canopy there is a large number of young plants $(96.6 \%)$ from self-seeding underbrush and shrublike forms aged 2-3 to 5-10 years and undergrowth aged $18-20$ years, including maple $-54 \%$, common hackberry $22 \%$, caucasian hackberry $-8 \%$, green ash $-5 \%$, common maple $-4 \%$, european white elm $-3 \%$, common ash $-2 \%$, ash maple $-2 \%$, false acacia, common oak and red oak, barberry, which appeared here by natural renewal (Fig. 3). Among these plants, the following species have been introduced: common hackberry, caucasian hackberry, green ash, ash maple, false acacia, which make up $37 \%$ of the total number of self-restored woody plants. The grass cover is formed by such species as lesser periwinkle (Vinca minor L.), wood violet, greater celandine (Chelidonium majus L.), bulbous flowering plant (Allium triquetrum L.).
In the stand and in the bush tier in the trial area 3 following plants are presented: field maple, Notway maple, honey locust (Gleditsia triacanthos L.), European ash, ash-leaf maple, sycamore maple (Acer pseudoplatanus L.), European white elm, pedunculate oak. There are also single plants of such species: false acacia, common hackberry, northern red oak, white mulberry (Morus alba L.), green ash, horse chestnut (Aesculus hippocastanum L.), wild privet (Ligustrum vulgare L.). The height of the stand in the plantation is $15-20 \mathrm{~m}$. Its upper tier includes - false acacia, honey locust $(1.15 \%$ of the total number of woody plants). All these are artificially planted plants, with the current age of 70-73 years.

There is also a large number of young plants $(98.8 \%)$, including field maple $-34 \%$, norway maple $-26 \%$, honey locust $-17 \%$, european ash $-9 \%$, ash-leaf maple $-4 \%$,

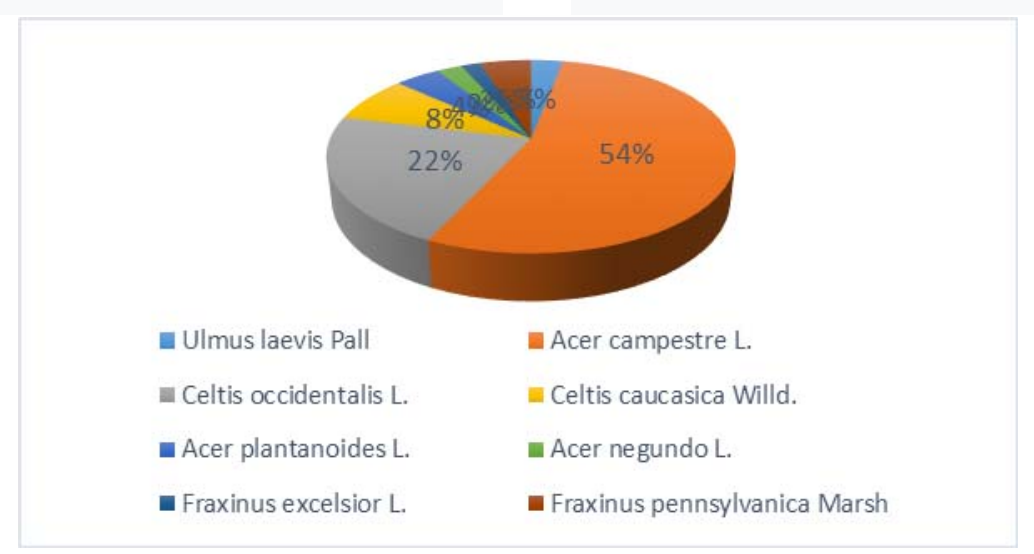

Fig. 3. The ratio of woody plant species of seed restoration in the trial area 2

maple (sycamore) $-3 \%$, european white elm $-2 \%$, pedunculate oak - $2 \%$, common hackberry, false acacia, northern red oak, white mulberry, green ash, horse chestnut, wild privet, which grew by natural regeneration (Fig. 4). Among these plants the following species are introduced: honey locust, ash-leaf maple, common hackberry, white mulberry, false acacia, northern red oak, horse chestnut, which make up $24 \%$ of the total number of woody plants that were self-restored. The total closure of the canopy in the plantation reaches $0.8-0.9$, the light structure is partial shade with separate windows, the type of moisture is fresh. The grass cover is formed by the following species: wood violet, hairy violet (Viola hirta L.), wood bluegrass (Poa nemoralis L.), clivers (Galium aparine L.), erect hedgeparsley (Torilis japonica (Hout) DC.), Cocc's-foot (Dactylis glomerata L.), spring sedge (Carex praecox Schreb.), Wood avens (Geum urbanum L.), greater celandine (Chelidonium majus L.). The main phase of grass formation belongs to the spring and early summer period. Presence of mushrooms in the plantation is typical; St. George's mushroom (Calocybe gambosa (Fr.) Donk) is possible to occur among them.
Numerous seed restoration of both aboriginal and introduced species of woody plants was detected in the test plots. In particular, in the trial area 1 numerous seed selfrestoration of autochthonous species was found. These are: Norway maple, European ash, field maple, and common oak, which make up $57 \%$ of the total number of restored woody plants. There is an intensive self-restoration of introduced species, potentially invasive plant species, such as ash-leaf maple, green ash, common hackberry, Asiatic elm, Virginia bird cherry, Tatarian honeysuckle, which make up $43 \%$ of the total number of self-restored woody plants. Numerous seed self-regeneration of autochthonous species, namely field maple, Norway maple, European white elm, European ash, was found on the trial area 2 , which is $63 \%$ of the total number of regenerated woody plants. Self-restoration of woody introduced species, namely, common hackberry, Caucasian hackberry, green ash, ash-leaf maple, false acacia is less intensive, and is $37 \%$.

Numerous seed self-restoration of autochthonous species was also detected in the trial area 3. These are: field maple, Norway maple, European ash, sycamore maple, European 


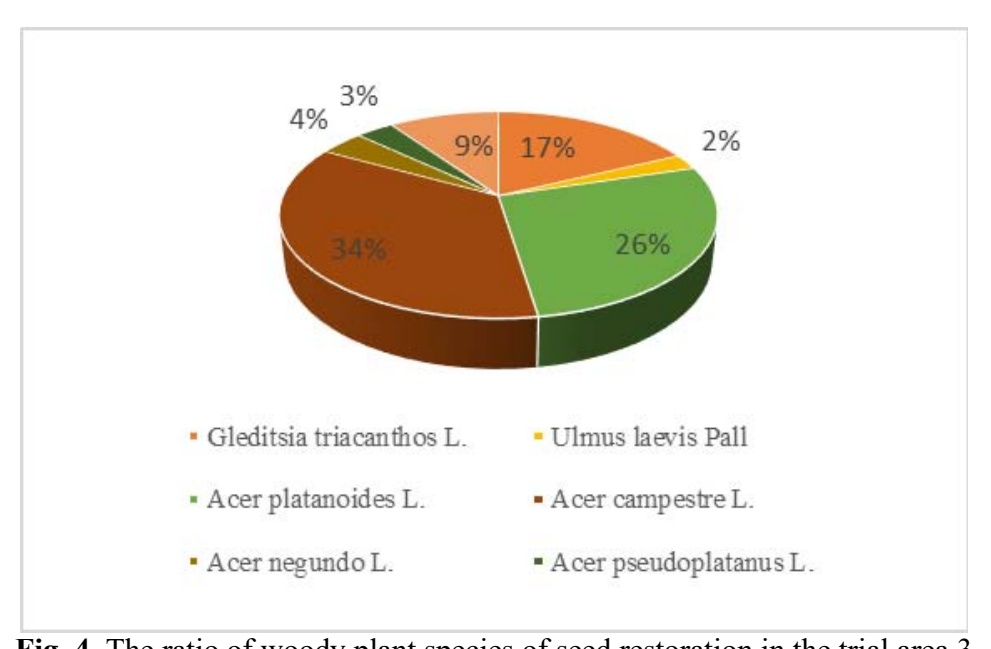

Fig. 4. The ratio of woody plant species of seed restoration in the trial area 3

white elm, common oak, which is $76 \%$ of the total number of restored woody plants. The number of undergrowth of field maple, Norway maple, honey locust is quite large. Selfrestoration of woody introduced species is less intensive and accounts for $24 \%$ of the total number of self-restored woody plants. These are: honey locust, ash-leaf maple, common hackberry, white mulberry, false acacia, northern red oak, horse chestnut, green ash. The viability of grasses under the stand canopy remains stable and high enough, but it is unlikely to compete with self-seeding of woody plants. Further development of self-restored species is determined by the influence of general light except for restrictions on emergence and further growth of oak. Individual acorn seedlings can germinate, but the sprouts soon turn into sticks and die, except for positions on the edges of the plantation with sufficient light and lack of competition from xerophilous grasses.

Since the plantations on the trial plots are based on artificial origin, the relationship between aboriginal species and introductory species is laid down mainly by humans and is in favor of indigenous species, due to better adaptability of local tree species to steppe climates. However, we did not notice any special competition between indigenous and introduced species. Each of the tree species has adapted quite well to the conditions of the ecotope and to the conditions of its specific place of growth. Bioecological features of wood species in the plantations from our point of view are not an obstacle to the development of the internal space of the ecotope. Shady areas in the plantations are groups of more compatible species of oaks, maples, ash and even hackberry and honey locust, which are more demanding to light and it is natural to combine them with the same ash, maple, false acacia and with shrubs of wild privet (Ligustrum vulgare L.) and mulberry, occupying mostly lawn positions.

\section{Conclusions}

Thus, in the three trial areas in the forest park and park part of the Botanical Garden of DNU aboriginal species form the bulk of woody plants restored by seeds. In general, it can be argued that mostly the stands of indigenous species are capable of forming a sufficient number of viable undergrowth, which will make it possible to form stands of natural origin; however the share of undergrowth of invasive species is also high. It can also be concluded that provided that human intervention does not interfere with natural processes, in the area under artificial woody plantations in the steppe zone of Ukraine, namely in the Botanical Garden of DNU there are processes that can lead to the formation of natural forest plant communities, which can also be proved by the results of the study of soil cover.

\section{References}

Belgard, A. L. (1950). Forest vegetation of the south-east of the Ukrainian SSR. Kiev, KSU (in Russian).

Kabar, A. M. (2003). Biological and ecological properties of the soil cover of the Botanical Garden of Dnipropetrovsk National University (formation, development, rational use). Dissertation for the degree of Candidate of Biological Sciences, Dnipropetrovsk, Ukraine (in Ukrainian).

Kavun, M. E., Savchuk, V. S., Opanasenko, V. F. \& Pakhomov, O. Y. (2009). History of the Botanical Garden of Dnipropetrovsk National University. Oles Honchar. Introduction of plants, 2, 114-121 (in Ukrainian).

Kohno, M. A. (2007). History of introduction of woody plants in Ukraine (short essay). Kyiv, Phytosocial Center (in Ukrainian).

Kuznetsov, S. I., Sliusar, S. I. \& Kuznetsova, M. S. (2017). Introduction of woody plants in Ukraine: past, present and future. Forestry and horticulture, 11, 1-13 (in Ukrainian).

Laptiev, O. O. (2001). Introduction and acclimatization of plants with basics of landscaping. Kyiv, Phytosocial Center (in Russian).

Onishchenko, V. M. (ed.) (2007). Project of organization of the territory of the Botanical Garden as an institution of the nature reserve fund of Ukraine of Dnipropetrovsk National University. (Vol. 1). Kyiv, NDPI mistobuduvannya (in Ukrainian)

Polyakov, O. K. (2009). Introduction of woody plants in a man-made environment. Donetsk, Knowledge (in Russian).

Suslova, O. P., Polyakov, O. K., \& Kharkhota, L. V. (2013). Condition of woody plants in park plantations of industrial cities of the south-east of Ukraine. Industrial botany, 13 (in Russian). 